SUMMARY OF REPORTED AGRICULTURE AND IRRIGATION WATER USE IN DESHA COUNTY, ARKANSAS, 1991

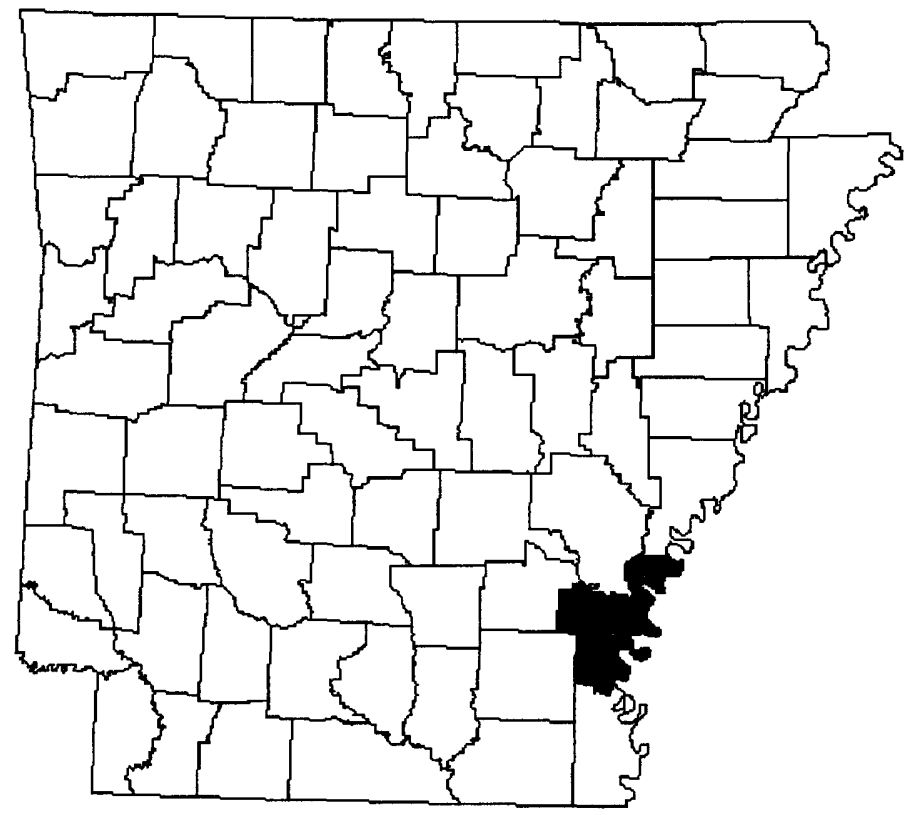

U.S. Department of the Interior U.S. Geological Survey Open-File Report 93-428

Prepared in cooperation with the Arkansas Soil and Water Conservation Commission 


\title{
SUMMARY OF REPORTED AGRICULTURE AND IRRIGATION WATER USE IN DESHA COUNTY, ARKANSAS, 1991
}

\author{
By Terrance W. Holland and Carolyn A. Manning
}

Water is one of Arkansas' most valuable resources. Sitespecific water-use data for several categories are collected and compiled annually by the Arkansas Soil and Water Conservation Commission (ASWCC) in cooperation with the U.S. Geological Survey. Data for the agriculture (nonirrigation) and irrigation categories are reported through the Conservation District Offices in each county.

This report summarizes the 1991 water-use reporting through the Conservation District Office in Desha County, Arkansas. The number of withdrawal registrations for Desha County was 1,737 (1,204 ground water and 533 surface water). Water withdrawals reported during the registration process total 18.67 million gallons per day (Mgal/d) (10.93 $\mathrm{Mgal} / \mathrm{d}$ ground water and $7.74 \mathrm{Mgal} / \mathrm{d}$ surface water) for agriculture and $228.17 \mathrm{Mgal} / \mathrm{d}(170.17 \mathrm{Mgal} / \mathrm{d}$ ground water and $58.00 \mathrm{Mgal} / \mathrm{d}$ surface water) for irrigation.

Of the total amount of water withdrawn (246.84 Mgal/d), 262,984 acre-feet per year (234.81 Mgal/d) can be accounted for by application type (table 1). The registration reports for 1991 indicate that this water was applied to 134,591 acres of land to irrigate rice, corn, soybeans, milo, cash grains, cotton, and hay as well as for the agricultural uses of animal aquaculture, timber, and ducks. There is a difference between total amount of water withdrawn and the reported quantity of water applied for agriculture and irrigation (12.03 Mgal/d) because some water is diverted to holding reservoirs, and because crop type or acreage delineation are incomplete on some reporting forms.

Water-use data collected in Desha County are used in various State/Federal/Cooperative projects. The objectives of these projects are to enhance the water-resources knowledge base and to provide water managers with the best possible information to help ensure that water of suitable quality continues to be available in sufficient quantities to meet water demands. Current projects include: the Eastern Arkansas Optimization modeling project and the National Water Use Information Program. 
Ground- and surface-water withdrawal locations in Desha County, Arkansas, 1991

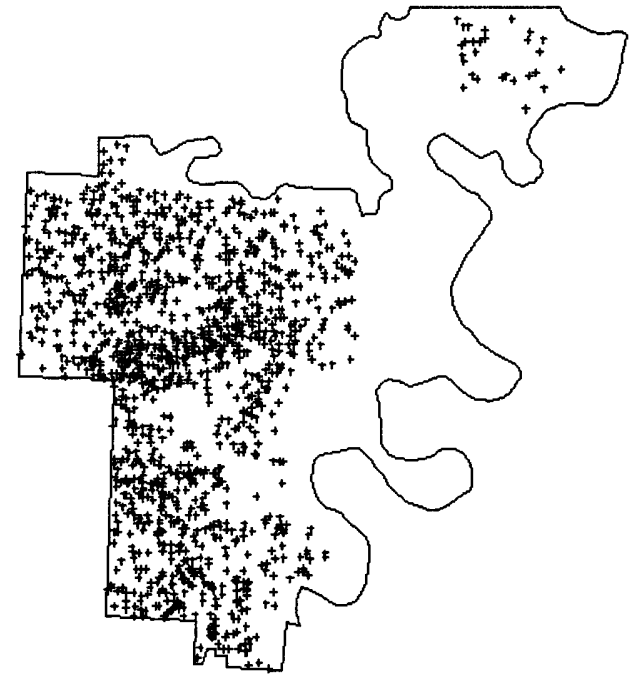

Ground-water withdrawal locations are represented by a "t".

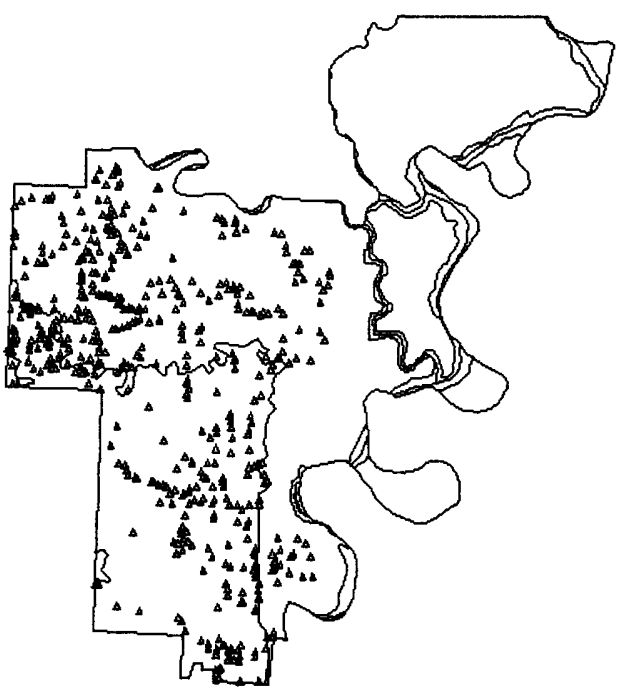

Surface-water withdrawal locations are represented by a " $\Delta$ ". 


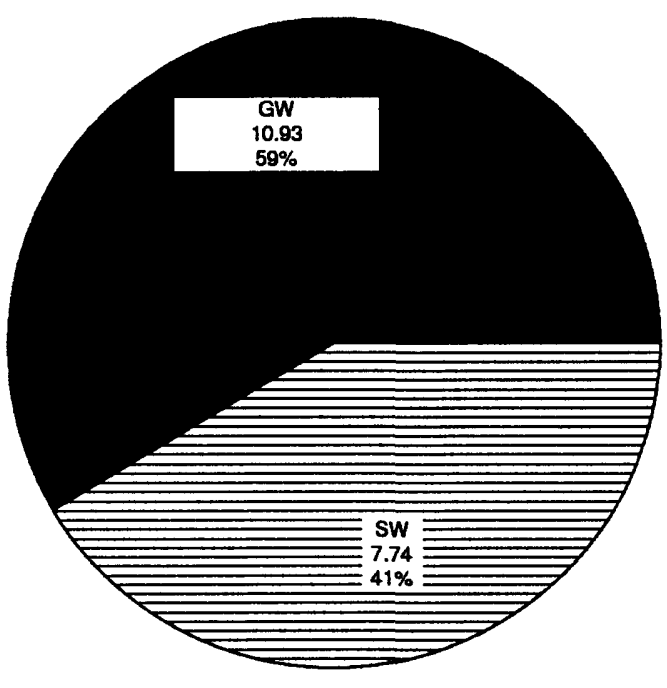

Percentage of ground- (GW) and surface-water (SW) withdrawals for the agriculture (non-irrigation) wateruse category in Desha County, Arkansas, 1991 (in million gallons per day)

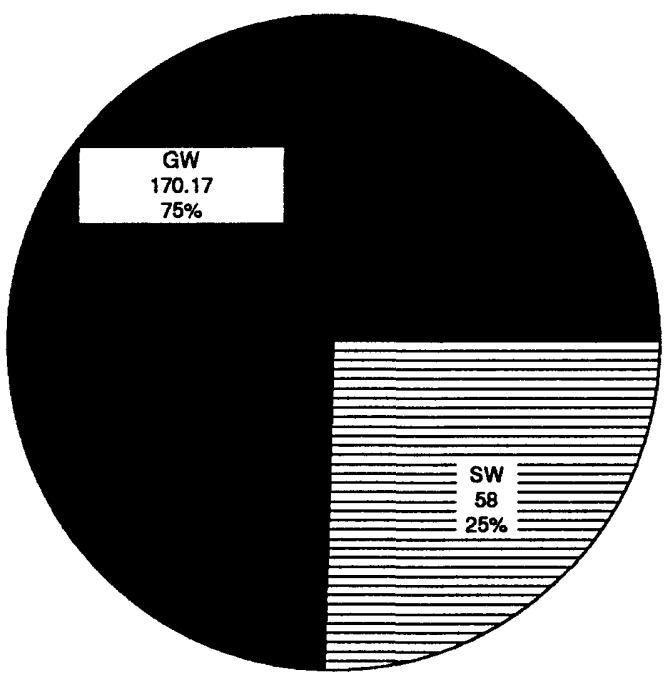

Percentage of ground- (GW) and surface-water (SW) withdrawals for the irrigation water-use category in Desha County, Arkansas, 1991 (in million gallons per day) 


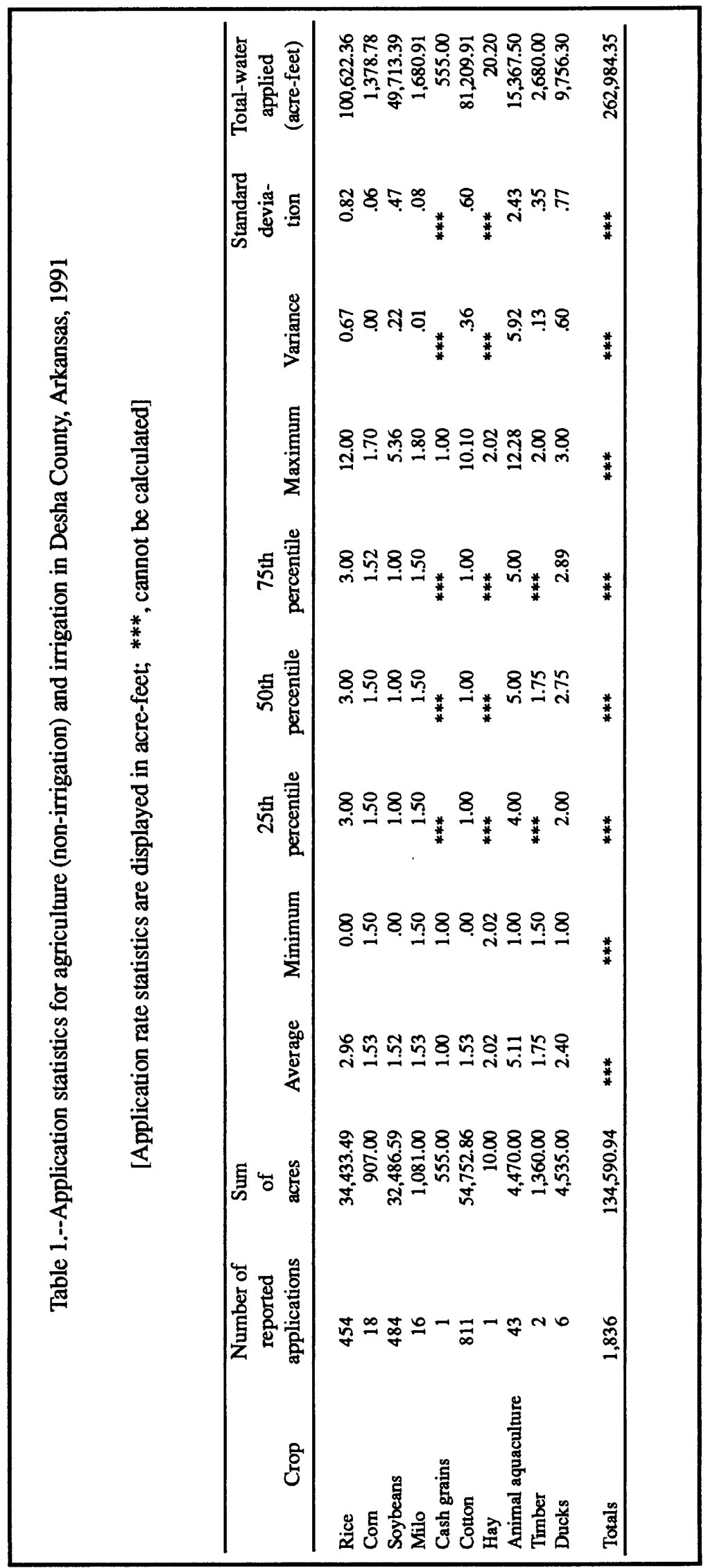




\section{Water-Use Reporting}

Act 81 of 1957, as amended, requires all diverters of water from streams, lakes, or ponds to register their diversion of surface water by quantity, location, type of use, and name of user on an annual basis with the ASWCC. The ASWCC is required to furnish each registrant a Certificate of Registration. The ASWCC utilizes these registrations for the allocation of water and as a basis for determining the State's overall water usage and water needs for inclusion in the Arkansas Water Plan.

Act 1051 of 1985 requires all users of ground water, excluding domestic use and wells having a maximum potential flow of less than 50,000 gallons per day, to register their withdrawal of ground water. The quantity, location, type of use, and name of user must be registered on an annual basis with the ASWCC or their local conservation district.

Act 154 of 1991 provides the ASWCC the authority to develop a comprehensive ground-water protection program, designate critical ground-water areas, cost-share on installation of water conservation practices, establish groundwater rights within critical areas, establish fees for groundand surface-water withdrawals, develop an education and information program, and delegate management powers to regional water districts and conservation districts. The intent of this program is to protect ground water for the future. The act also establishes as State policy, that if reductions in well pumpage are necessary, it is most desirable that the reductions come from conservation programs and the utilization of surface water. However, if necessary, the ASWCC may limit ground-water withdrawals through the issuance of water rights in critical ground-water areas. 
There are several important facts that should be noted in reference to Act 154 of 1991:

1.The effective date of this act is October 1,1992.

2. The act provides for the assessment of annual water-use fees in the amount of $\$ 10$ per registered surface-water diversion and $\$ 10$ per registered well, which is payable at the time of water-use reporting.

3. Fees collected will be utilized for cost-sharing on waterconservation practices, administration, and education programs.

4.The period for registration and reporting extends annually from October 1 through March 31. 
For additional information write to:

District Chief

U.S. Geological Survey

2301 Federal Office Building

700 West Capitol Avenue

Little Rock, Arkansas 72201

Copies of this report can be purchased from:

U.S. Geological Survey

Books and Open-File Reports Section Federal Center

Box 25425

Denver, Colorado 80225

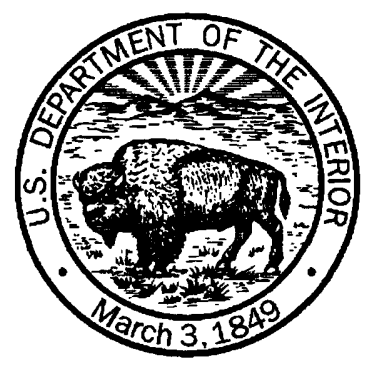

